\title{
Diurnal variation in mesophyll conductance and its influence on modelled water-use efficiency in a mature boreal Pinus sylvestris stand
}

\author{
Zsofia R. Stangl ${ }^{1} \cdot$ Lasse Tarvainen $^{1,2} \cdot$ Göran Wallin $^{2} \cdot$ Nerea Ubierna $^{3} \cdot$ Mats Räntfors $^{2} \cdot$ John D. Marshall ${ }^{10}$
}

Received: 2 August 2018 / Accepted: 6 May 2019 / Published online: 23 May 2019

(c) The Author(s) 2019

\begin{abstract}
Mesophyll conductance $\left(g_{\mathrm{m}}\right)$ is a critical variable for the use of stable carbon isotopes to infer photosynthetic water-use efficiency (WUE). Although $g_{\mathrm{m}}$ is similar in magnitude to stomatal conductance $\left(g_{\mathrm{s}}\right)$, it has been measured less often, especially under field conditions and at high temporal resolution. We mounted an isotopic $\mathrm{CO}_{2}$ analyser on a field photosynthetic gas exchange system to make continuous online measurements of gas exchange and photosynthetic ${ }^{13} \mathrm{C}$ discrimination $\left(\Delta^{13} \mathrm{C}\right)$ on mature Pinus sylvestris trees. This allowed the calculation of $g_{\mathrm{m}}, g_{\mathrm{s}}$, net photosynthesis $\left(A_{\mathrm{net}}\right)$, and WUE. These measurements highlighted the asynchronous diurnal behaviour of $g_{\mathrm{m}}$ and $g_{\mathrm{s}}$. While $g_{\mathrm{s}}$ declined from around 10:00, $A_{\text {net }}$ declined first after 12:00, and $g_{\mathrm{m}}$ remained near its maximum until 16:00. We suggest that high $g_{\mathrm{m}}$ played a role in supporting an extended $A_{\text {net }}$ peak despite stomatal closure. Comparing three models to estimate WUE from $\Delta{ }^{13} \mathrm{C}$, we found that a simple model, assuming constant net fractionation during carboxylation (27\%o), predicted WUE well, but only for about $75 \%$ of the day. A more comprehensive model, accounting explicitly for $g_{\mathrm{m}}$ and the effects of daytime respiration and photorespiration, gave reliable estimates of WUE, even in the early morning hours when WUE was more variable. Considering constant, finite $g_{\mathrm{m}}$ or $g_{\mathrm{m}} / g_{\mathrm{s}}$ yielded similar WUE estimates on the diurnal scale, while assuming infinite $g_{\mathrm{m}}$ led to overestimation of WUE. These results highlight the potential of high-resolution $g_{\mathrm{m}}$ measurements to improve modelling of $A_{\text {net }}$ and WUE and demonstrate that such $g_{\mathrm{m}}$ data can be acquired, even under field conditions.
\end{abstract}

Keywords Carbon isotope ratio $\cdot$ Cavity ring-down absorption spectrometry $\cdot$ Online discrimination $\cdot$ Vapour pressure deficit · Photosynthesis

\section{Abbreviations}

$A_{\text {net }} \quad$ Net photosynthesis rate $\left(\mu \mathrm{mol} \mathrm{CO} \mathrm{Cm}^{-2} \mathrm{~s}^{-1}\right)$

$\Delta_{\mathrm{e}} \quad$ Discrimination associated with respiration (\%o)

$\Delta_{\mathrm{f}} \quad$ Discrimination associated with photorespiration $(\%)$

Electronic supplementary material The online version of this article (https://doi.org/10.1007/s11120-019-00645-6) contains supplementary material, which is available to authorized users.

John D. Marshall

john.marshall@slu.se

1 Department of Forest Ecology and Management, Swedish University of Agricultural Sciences, Umeå, Sweden

2 Department of Biological and Environmental Sciences, University of Gothenburg, Gothenburg, Sweden

3 Research School of Biology, The Australian National University, Canberra, ACT, Australia
$\Delta_{\mathrm{i}} \quad$ Discrimination when $C_{\mathrm{i}}=C_{\mathrm{c}}(\% \mathrm{o})$

$\Delta_{\mathrm{o}} \quad$ Observed photosynthetic discrimination (\%o)

$a_{\mathrm{m}} \quad{ }^{12} \mathrm{C} /{ }^{13} \mathrm{C}$ fractionation during dissolution and diffusion through water $1.8(\%)$

$a_{\mathrm{s}} \quad{ }^{12} \mathrm{C} /{ }^{13} \mathrm{C}$ fractionation during diffusion through air $4.4(\% \circ)$

${ }^{12} \mathrm{C} /{ }^{13} \mathrm{C}$ fractionation during carboxylation 29 (\%o)

$\bar{b} \quad{ }^{12} \mathrm{C} /{ }^{13} \mathrm{C}$ net fractionation during carboxylation 27 (\%o)

$C_{\mathrm{c}} \quad \mathrm{CO}_{2}$ concentration in the chloroplast $\left(\mu \mathrm{mol} \mathrm{mol}{ }^{-1}\right)$

$C_{\mathrm{i}} \quad \mathrm{CO}_{2}$ concentration in the intercellular space ( $\mu \mathrm{mol} \mathrm{mol}{ }^{-1}$ )

$C_{\text {in }} \quad \mathrm{CO}_{2}$ concentration in the air entering the cuvette $\left(\mu \mathrm{mol} \mathrm{mol}{ }^{-1}\right)$ 


\begin{tabular}{|c|c|}
\hline$C_{\text {out }}$ & $\mathrm{CO}_{2}$ concentration in the cuvette $\left(\mu \mathrm{mol} \mathrm{mol}{ }^{-1}\right)$ \\
\hline E & Transpiration rate $\left(\mathrm{mmol} \mathrm{H}_{2} \mathrm{O} \mathrm{m}^{-2} \mathrm{~s}^{-1}\right)$ \\
\hline$e$ & Fractionation during respiration (\%o) \\
\hline$f$ & Fractionation during photorespiration $16.2(\%)$ \\
\hline$g_{\mathrm{m}}$ & Mesophyll conductance $\left(\mathrm{mol} \mathrm{CO} \mathrm{Cm}^{-2} \mathrm{~s}^{-1} \mathrm{bar}^{-1}\right)$ \\
\hline$g_{\mathrm{s}}$ & Stomatal conductance $\left(\mathrm{mol} \mathrm{CO}_{2} \mathrm{~m}^{-2} \mathrm{~s}^{-1} \mathrm{bar}^{1}\right)$ \\
\hline$R_{\mathrm{d}}$ & Day time respiration rate $\left(\mu \mathrm{mol} \mathrm{CO} \mathrm{Cm}_{2} \mathrm{~m}^{-1}\right)$ \\
\hline$R_{\mathrm{p}}$ & Photorespiration rate $\left(\mu \mathrm{mol} \mathrm{CO} \mathrm{Cm}^{-2} \mathrm{~s}^{-1}\right)$ \\
\hline$t$ & Ternary correction factor $(-)$ \\
\hline VPD & Vapour pressure deficit $(\mathrm{kPa})$ \\
\hline WUE & Water-use efficiency $\left(\mathrm{mmol} \mathrm{CO}_{2} \mathrm{~mol}^{-1} \mathrm{H}_{2} \mathrm{O}\right)$ \\
\hline $\mathrm{WUE}_{\mathrm{G}}$ & $\begin{array}{l}\text { WUE from gas exchange }\left(\mathrm{mmol} \mathrm{CO}_{2} \mathrm{~mol}^{-1}\right. \\
\left.\mathrm{H}_{2} \mathrm{O}\right)\end{array}$ \\
\hline $\mathrm{WUE}_{\Delta}$ & $\begin{array}{l}\text { WUE calculated from } \Delta^{13} \mathrm{C}\left(\mathrm{mmol} \mathrm{CO}_{2} \mathrm{~mol}^{-1}\right. \\
\left.\mathrm{H}_{2} \mathrm{O}\right)\end{array}$ \\
\hline$\Gamma^{*}$ & $\mathrm{CO}_{2}$ compensation point $\left(\mu \mathrm{mol} \mathrm{mol}{ }^{-1}\right)$ \\
\hline
\end{tabular}

\section{Introduction}

Mesophyll conductance $\left(g_{\mathrm{m}}\right)$ describes the ability of $\mathrm{CO}_{2}$ to diffuse across the interior of the leaf. In plants with $\mathrm{C}_{3}$ photosynthesis, $g_{\mathrm{m}}$ is roughly similar in magnitude to stomatal conductance $\left(g_{\mathrm{s}}\right)$, frequently accounting for about $40 \%$ of the decline in $\mathrm{CO}_{2}$ concentration from the ambient atmosphere to the chloroplasts $\left(C_{\mathrm{c}}\right)$ (Flexas et al. 2008; Warren 2008a). As a consequence, it has an important place in leaf-level photosynthesis models (von Caemmerer 2000; Dewar et al. 2017), but has been so infrequently quantified that it is seldom included in earth-system models (Rogers et al. 2017). It also has a critical role in the inference of water-use efficiency (WUE) from stable carbon isotope composition $\left(\delta^{13} \mathrm{C}\right)$ of plant tissues or, conversely, in the inference of $\delta^{13} \mathrm{C}$ from gas exchange (Rogers et al. 2017). This role is caused by the decrease in $\mathrm{CO}_{2}$ concentration at the enzyme rubisco, where $\delta^{13} \mathrm{C}$ is determined, relative to the substomatal cavities, where WUE is determined. Mesophyll conductance provides a means to calculate this difference. If $g_{\mathrm{m}}$ could be accounted for, then $\delta^{13} \mathrm{C}$ could provide independent tests of the WUE predictions of leaf (von Caemmerer 2000; Wei et al. 2014), canopy (Keenan et al. 2013), and earth-system models (Rogers et al. 2017).

One reason for the relative paucity of $g_{\mathrm{m}}$ data is that it is more difficult to estimate than $g_{\mathrm{s}}$. Stomatal conductance to $\mathrm{CO}_{2}$ is easily estimated from humidity, temperature and transpiration measurements, which might come from leaflevel gas exchange or sap-flux data. Given the relative ease of making such measurements, high temporal resolution $g_{\mathrm{s}}$ data are available for many species and sites, and models of $g_{\mathrm{s}}$ based on theory and empirical data have converged (Medlyn et al. 2011) and been incorporated into global models (Prentice et al. 2014; Rogers et al. 2017). In contrast, measuring $g_{\mathrm{m}}$ requires simultaneous measurements of gas exchange and either chlorophyll fluorescence or photosynthetic discrimination against ${ }^{13} \mathrm{C}\left(\Delta^{13} \mathrm{C}\right)$. Discrimination can be inferred from the $\delta^{13} \mathrm{C}$ signature of photosynthesis products, e.g. leaf soluble sugars, phloem contents, plant tissues (e.g.: Hu et al. 2010; Ubierna and Marshall 2011), or directly from leaf $\mathrm{CO}_{2}$ flux (e.g.: Evans et al. 1986; Warren et al. 2003; Bickford et al. 2009; Wingate et al. 2007, 2010; Maseyk et al. 2011; Campany et al. 2016). These methods are technically challenging, especially under field conditions, so that measurements are often made with low temporal resolution.

It has been difficult to model $g_{\mathrm{m}}$, because previous studies have found that $g_{\mathrm{m}}$ and $g_{\mathrm{s}}$ respond differently to changes in environmental conditions, suggesting that the two are not tightly coupled. Rapid responses of $g_{\mathrm{m}}$ have been described to several environmental variables (for a review see Flexas et al. 2008; Warren 2008a; Flexas et al. 2012). These variables include light intensity or quality (Flexas et al. 2007; Tholen et al. 2008; Hassiotou et al. 2009; Loreto et al. 2009; Campany et al. 2016), intercellular $\mathrm{CO}_{2}$ concentration $\left(C_{\mathrm{i}}\right)$ (Flexas et al. 2007; Hassiotou et al. 2009; Vrábl et al. 2009; Bunce 2010; Douthe et al. 2011; Tazoe et al. 2011), and leaf temperature (Bernacchi et al. 2002; Yamori et al. 2006; Warren 2008b; Evans and von Caemmerer 2013). If $g_{\mathrm{s}}$ responded to other variables, or at different rates, then the ratio $g_{\mathrm{m}} / g_{\mathrm{s}}$ would change. For example, it has been shown that $g_{\mathrm{m}}$ responds similarly, but more quickly, to variable $C_{\mathrm{i}}$ than $g_{\mathrm{s}}$ (Flexas et al. 2007). In addition, the $g_{\mathrm{m}} / g_{\mathrm{s}}$ ratio was found to be temperature dependent in a study exploring the thermal acclimation of $g_{\mathrm{m}}$ in spinach (Yamori et al. 2006).

Vapour pressure deficit (VPD) is particularly interesting in this context, because $g_{\mathrm{s}}$ responds so strongly to it (Marshall and Waring 1984; Oren et al. 1999; Medlyn et al. 2011). In contrast, the response of $g_{\mathrm{m}}$ to VPD has not been extensively studied and the results so far are contradictory (Bongi and Loreto 1989; Warren 2008c, Loucos et al. 2017). Both temperature and VPD change dynamically under natural conditions, diurnally and seasonally, potentially influencing the $g_{\mathrm{s}}$ to $g_{\mathrm{m}}$ relationship. However, the magnitude and importance of this variability has yet to be explored.

Given constant $g_{\mathrm{s}}$, an increase in $g_{\mathrm{m}}$ would increase wateruse efficiency (WUE) (Flexas et al. 2010; Galmés et al. 2011), which is defined as the ratio of net carbon assimilation $\left(A_{\text {net }}\right)$ to water loss through transpiration $(E)$. This would happen because an increase in $g_{\mathrm{m}}$ has no direct effect on transpiration, but it increases photosynthesis, resulting in an increase of the $A_{\text {net }} / E$ ratio. Accounting for $g_{\mathrm{m}}$ is especially important when estimating WUE from $\delta^{13} \mathrm{C}$. For example, WUE is often inferred from historic tree-ring isotope data (Marshall and Monserud 1996; Seibt et al. 2008; Voelker et al. 2016). Such inferences require that some value for $g_{\mathrm{m}}$ be assumed. This assumption is often embedded as a constant, empirical adjustment in the relationship between 
$C_{\mathrm{i}} / C_{\mathrm{a}}$ and isotopic discrimination (Farquhar et al. 1982), or extrapolated based on its correlation with $g_{\mathrm{s}}$ in models of WUE (Klein et al. 2015), although as noted above, the correlation with $\mathrm{g}_{\mathrm{s}}$ is not always strong.

In this manuscript, we present continuous, simultaneous measurements of shoot-scale gas exchange and ${ }^{13} \mathrm{C}$ discrimination in a 100-year-old Pinus sylvestris stand in northern Sweden. We use these simultaneous data streams to obtain hourly $g_{\mathrm{m}}$ estimates parallel to $g_{\mathrm{s}}, A_{\text {net }}$ and $E$. We begin with a brief description of how the data were treated and evaluate the accuracy of our measurement system. We next explore the diurnal dynamics of $g_{\mathrm{s}}$ and $g_{\mathrm{m}}$ and their relationship to $A_{\text {net }}$. Finally, we compare estimates of WUE derived from gas exchange $\left(\mathrm{WUE}_{\mathrm{G}}\right)$ with estimates derived from photosynthetic discrimination $\left(\mathrm{WUE}_{\Delta}\right)$. Three photosynthetic discrimination $\left(\Delta^{13} \mathrm{C}\right)$ models were used to calculate $\mathrm{WUE}_{\Delta}$ : a comprehensive model, a partial model and a simple model. Additionally, the comprehensive model was applied using three different assumptions for $g_{\mathrm{m}}$ values. We compare the different models and calculations and discuss their impact on $\mathrm{WUE}_{\Delta}$ estimates.

\section{Materials and methods}

\section{Description of the experimental site}

The study was conducted in a 100-year-old, naturally regenerated, even-aged stand of Pinus sylvestris (Scots pine) at the Rosinedalsheden experimental forest in northern Sweden $\left(64^{\circ} 10^{\prime} \mathrm{N}, 19^{\circ} 45^{\prime} \mathrm{E}, 153 \mathrm{~m}\right.$ above see level), during the growing season of 2017. The Rosinedalsheden experiment includes an intensive fertilisation treatment (Lim et al. 2015), but the current study was conducted entirely on the unfertilised area. The photosynthetic season typically extends from mid-April to mid-November, buds burst at the end of May, and stem diameter-growth ceases in late August (Tarvainen et al. 2018). The June to August mean temperature was $12.4 \pm 0.8{ }^{\circ} \mathrm{C}($ mean $\pm \mathrm{SD})$ and the mean monthly precipitation was $67.9 \pm 8.6 \mathrm{~mm}$ (mean $\pm \mathrm{SD})$, based on the 15-year (2003-2017) data measured at the Vindeln-Sunnansjönäs meteorological station (Swedish Meteorological and Hydrological Institute, www.smhi.se) approximately $5 \mathrm{~km}$ from the experimental site. The site has weakly podzolised fine sandy soil with a thin $(2-5 \mathrm{~cm})$ organic layer (Hasselquist et al. 2012). The leaf area index was 2.7 and the average tree height was $18.6 \pm 2.3 \mathrm{~m}($ mean $\pm \mathrm{SD})$ in 2013 (Lim et al. 2015).

\section{Experimental setup for continuous measurements of gas exchange}

Shoot gas exchange $\left(\mathrm{CO}_{2}\right.$ and $\left.\mathrm{H}_{2} \mathrm{O}\right)$ was measured continuously on one 1-year-old upper canopy shoot on four trees.
A 16-m tall scaffolding tower was used to reach the shoots and secure the equipment. The shoot-scale gas exchange was measured using a custom-built multichannel gas exchange system (GUS) (Wallin et al. 2001; Tarvainen et al. 2016), equipped with infrared gas analysers (IRGA, CIRAS-1, PP systems Hitchin Herts, U.K.) to measure $\mathrm{CO}_{2}$ and $\mathrm{H}_{2} \mathrm{O}$ partial pressure in the air from shoot cuvettes and reference channels. The $330 \mathrm{ml}$ shoot cuvettes had a transparent acrylic plastic (Plexiglas) top for natural illumination. The cuvettes were temperature $(\mathrm{T})$ controlled to track the ambient $\mathrm{T}$ and were equipped with a light sensor (PAR-1 M, PP systems, Hitchin, Herts, UK). The polyethylene tubing that connected the cuvettes to the IRGAs were insulated and heated with cables to avoid condensation. Nonetheless, morning condensation could occur in the cuvettes in connection with heavy rain events; we filtered those days out in the current analysis. The GUS cycled through the four shoot cuvettes and two non-cuvette lines once per hour, spending $7 \mathrm{~min}$ at each position, which were divided into $2 \mathrm{~min}$ of waiting time to allow instrument readings to stabilise and 5 min of measurement. We used the means from the 5-min measurement periods in the subsequent analyses, which yielded approximately one value/cuvette/hour throughout the 9 days. The non-cuvette lines were used for data quality assurance and for measurement of $\delta^{13} \mathrm{C}$ of ambient air (see details in next chapter). The IRGAs were calibrated with $400 \mu \mathrm{mol} \mathrm{mol}{ }^{-1} \mathrm{CO}_{2}$ gas at the beginning and at the end of the growing season. Additionally, every hour the IRGAs were zero calibrated and the system ran a cross-calibration protocol to match values in the sample and reference channels.

\section{Continuous measurement of $\delta^{13} \mathrm{C}$}

The isotopic composition of the $\mathrm{CO}_{2}$ in the air entering and leaving the cuvettes was analysed with a cavity ring-down spectrophotometer (CRDS; G2131-i, Picarro Inc., California, USA). The CRDS was connected to the same central line as the GUS, in parallel to the sample IRGA. We tested the instrument at varying $\mathrm{CO}_{2}$ and $\mathrm{H}_{2} \mathrm{O}$ vapour concentrations and found that the $\delta^{13} \mathrm{C}$ values were dependent on both, with an asymptotic relationship of $\delta^{13} \mathrm{C}$ to $\mathrm{CO}_{2}$ concentration (Fig. S1) and a linear dependency to $\mathrm{H}_{2} \mathrm{O}$ vapour concentration (Fig. S2). The continuous $\delta^{13} \mathrm{C}$ readings were corrected to account for the $\mathrm{CO}_{2}$ and $\mathrm{H}_{2} \mathrm{O}$ concentration effects before the data were used in further analyses. The CRDS was factory-calibrated in 2017 and manually calibrated once per week, using two reference gases with known $\mathrm{CO}_{2}$ concentrations $\left(411 \mu \mathrm{mol} \mathrm{mol}{ }^{-1}\right.$, $\left.\mathrm{SD}=5.1 ; 1606 \mu \mathrm{mol} \mathrm{mol}{ }^{-1}, \mathrm{SD}=13.1\right)$ and $\delta^{13} \mathrm{C}$ values $(-32.36 \%$ o, SD $=0.09 ;-4.14 \%$, SD $=0.06)$. The reference gases were analysed at the SLU Stable Isotope Laboratory (Umeå, Sweden) with GB-IRMS (Gasbench 
II-Isotope Ratio Mass Spectrometer, Thermo Fisher Scientific, Bremen, Germany), which was calibrated against IAEA-co-9 and NBS 19 standards. We found the weekly calibrations to be sufficient, because the reference $\delta^{13} \mathrm{C}$ values were stable over the season (Fig. S3) and were offset from the reference gases by a constant $4.17 \%$ $(\mathrm{SD}=0.1)$, after correction for $\mathrm{CO}_{2}$ concentration. The CRDS recorded $\delta^{13} \mathrm{C}$ values once per second during the 5-min calibration period, which were then combined into a mean for each calibration date and these means yielded standard deviations of $0.1 \%$ for $\delta^{13} \mathrm{C}$.

\section{Calculation of leaf gas exchange parameters and mesophyll conductance}

In this paper, we present data collected on nine sunny days during the summer (28th of June-2nd of July and 6th of July - 9th of July), with daily minimum and maximum temperatures of $6.2 \pm 0.5{ }^{\circ} \mathrm{C}$ and $24.4 \pm 0.6{ }^{\circ} \mathrm{C}$, respectively, and daily maximum irradiation of $1964 \pm 25 \mu \mathrm{mol} \mathrm{m}{ }^{-2} \mathrm{~s}^{-1}$. Because of the high latitude and season, sunrise was typically around 02:15 and sunset was around 23:00. These days were chosen for high photosynthetic rates and lack of condensation in the cuvettes and tubing. We optimised the system setup to yield clear and consistent $\delta^{13} \mathrm{C}$ values with the CRDS, using 5-min integrations at approximately 1-second intervals. Because each of these measurements contributed to the mean $\delta^{13} \mathrm{C}$ value, it was appropriate to calculate the standard error of the mean from them. This yielded high precision, typically $\mathrm{SE}<0.06 \%$.

$A_{\text {net }}, E, g_{\mathrm{s}}$, and $C_{\mathrm{i}}$ were calculated from the gas exchange data according to the model described by Farquhar et al. (1980). Boundary layer conductance has previously been found to be high $\left(8.1 \mathrm{~mol} \mathrm{H}_{2} \mathrm{O} \mathrm{m}^{-2} \mathrm{~s}^{-1}\right.$ ) (Uddling and Wallin 2012) in our gas exchange cuvettes, therefore, we assumed boundary layer resistance to be insignificant. Needles from the shoots enclosed in the cuvettes were collected at the end of the study campaign to determine the projected leaf area using a flat bed scanner (Epson 1600) equipped for dual scanning, and WinSEEDLE Pro 5.1a (Regent Instruments, Canada) analysis software.

Mesophyll conductance $\left(g_{\mathrm{m}}\right)$ and $C_{\mathrm{c}}$ were estimated from the carbon isotope discrimination data collected by the CRDS. The $g_{\mathrm{m}}$ was calculated from the comprehensive $\Delta{ }^{13} \mathrm{C}$ model of Farquhar and Cernusak (2012) that includes ternary corrections. In particular, we used the formulation of Evans and von Caemmerer (2013) (see supplementary materials for details) that calculates $g_{\mathrm{m}}$ as

$g_{\mathrm{m}}=\frac{\frac{1+t}{1-t}\left(b-a_{\mathrm{m}}-\frac{e R_{\mathrm{d}}}{A_{\text {net }}+R_{\mathrm{d}}}\right) \frac{A_{\text {net }}}{C_{\text {out }}}}{\Delta_{\mathrm{i}}-\Delta_{\mathrm{o}}-\Delta_{\mathrm{e}}-\Delta_{\mathrm{f}}}$ where $b, a_{\mathrm{m}}$ and $e$ are the fractionation factors during carboxylation $(b=29 \% o)$, dissolution and diffusion through water $\left(a_{\mathrm{m}}=1.8 \%\right)$ and respiration ( $e$, see Eqn. S5), respectively. $R_{\mathrm{d}}$ is daytime respiration (Eqn. $\mathrm{S} 1$ ), and $C_{\text {out }}{ }^{1}$ is the $\mathrm{CO}_{2}$ concentration in the cuvette; $\Delta_{\mathrm{i}}, \Delta_{\mathrm{o}}, \Delta_{\mathrm{e}}$ and $\Delta_{\mathrm{f}}$ are, respectively, the discrimination when $C_{\mathrm{i}}=C_{c}$ (Eqn. S2), the observed discrimination during gas exchange (Eqn. S3 and S4), the discrimination associated with respiration (Eqn. S5 and S6) and with photorespiration (Eqn. S7). The term $t$ is the ternary correction factor (Eqn. S8, Farquhar and Cernusak 2012). Note that $C_{\text {out }}$ is lower than the atmospheric $\mathrm{CO}_{2}$ concentration $\left(C_{\text {in }}\right)$, due to $A_{\text {net }}$ within the cuvette. The $\mathrm{CO}_{2}$ concentration at the site of carboxylation $\left(C_{\mathrm{c}}\right)$ was calculated from $g_{\mathrm{m}}$ through the following relationship:

$A_{\text {net }}=g_{\mathrm{m}}\left(C_{\mathrm{i}}-C_{\mathrm{c}}\right)$

We evaluated how the magnitude of the net photosynthetic $\mathrm{CO}_{2}$ drawdown, calculated as $C_{\text {in }}-C_{\text {out }}$, affected our estimates of $C_{\mathrm{c}}$. This drawdown, together with instrument precision, determines the error associated with $\Delta^{13} \mathrm{C}$ measurements, which ultimately determines the error in $C_{\mathrm{c}}$ and $g_{\mathrm{m}}$ estimates (for a discussion see Ubierna et al. 2018). The concentration drop is evaluated with the parameter $\zeta=C_{\text {in }}$ I $\left(C_{\text {in }}-C_{\text {out }}\right)$. Pons et al. (2009) showed that the error associated with $g_{\mathrm{m}}$ estimates increased when $\zeta$ was large and the instrument precision was low. We likewise found that $C_{\mathrm{c}}$ became exponentially more variable as the $\mathrm{CO}_{2}$ drawdown in the cuvette decreased below $20 \mu \mathrm{mol} \mathrm{CO}_{2} \mathrm{~mol}^{-1}$ (Fig. 1a). Assuming an ambient $\mathrm{CO}_{2}$ concentration of $400 \mathrm{ppm}$, a drawdown of $20 \mu \mathrm{mol} \mathrm{CO} \mathrm{mol}^{-1}$ corresponds to $\zeta=20$ $(=400 /(400-380))$. In this case, and with an instrument precision of $0.06 \%$ o the error associated with $\Delta{ }^{13} \mathrm{C}$ measurements was $1.7 \%$ o $(=\sqrt{2} \cdot \zeta \cdot$ Precision $)$. This low drawdown and large error mainly occurred during early mornings and evenings, so that it was not possible to acquire reasonable estimates before 04:00 and after 20:00 (Fig. 1b). For most of the day, the observed drawdown was substantially greater than $20 \mu \mathrm{mol} \mathrm{CO} \mathrm{mol}^{-1}$ which resulted in $\zeta<10$ and associated errors in $\Delta_{\mathrm{o}}<0.8 \%$ (Fig. 1b).

\section{Comparison of models to estimate water-use efficiency from $\Delta^{13} \mathrm{C}$}

Instantaneous WUE can be derived from $\Delta^{13} \mathrm{C}\left(\mathrm{WUE}_{\Delta}\right)$ or from gas exchange $\left(\mathrm{WUE}_{\mathrm{G}}\right.$ ) measurements as (Seibt et al. 2008; Hu et al. 2010; Wang et al. 2014; Klein et al. 2015; Guerrieri et al. 2016):

\footnotetext{
${ }^{1}$ In calculations based on on-line discrimination, we consider the $\mathrm{CO}_{2}$ concentration and the isotopic composition inside the cuvette (noted with the subscript 'out') as 'ambient' because they represent the immediate environment of the shoot or leaf. If the models presented here (Eqs. 1, 3, 4, 5) are to be applied elsewhere, $C_{\text {out }}$ can be replaced with $C_{\mathrm{a}}$ and ${ }^{13} C_{\text {out }}$ can be replaced with ${ }^{13} C_{\mathrm{a}}$.
} 


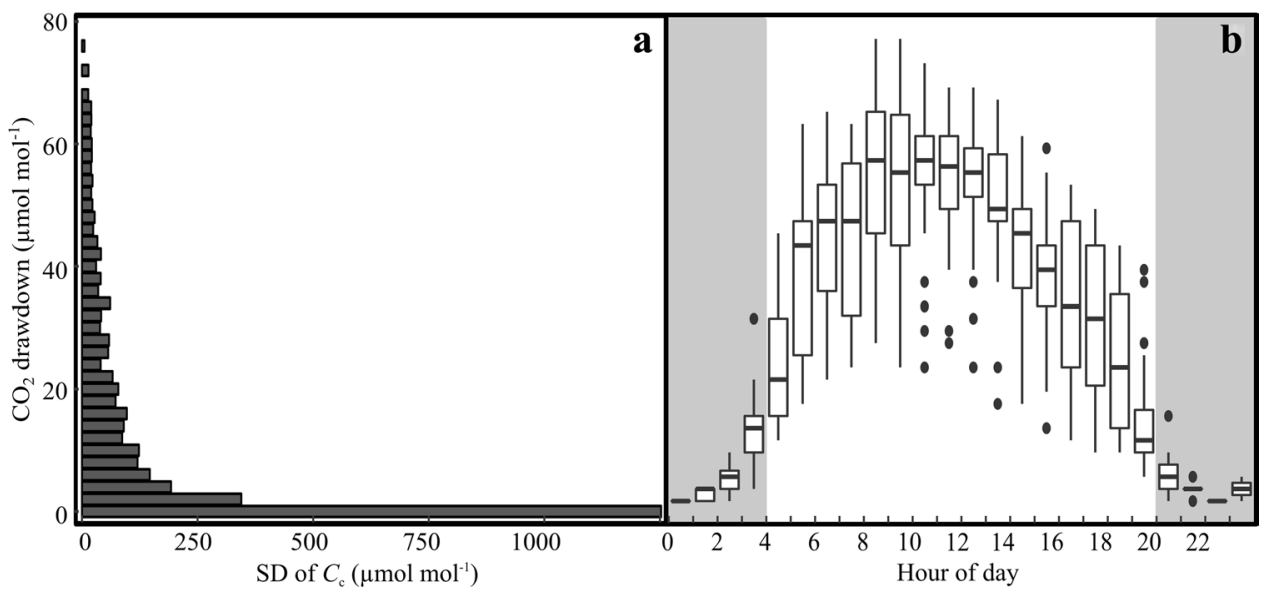

Fig. 1 a Standard deviation of the $\mathrm{CO}_{2}$ concentration in the chloroplast $\left(C_{\mathrm{c}}\right)$ in relation to $\mathrm{CO}_{2}$ drawdown in the cuvette, defined as the difference between the atmospheric concentration $\left(C_{\text {in }}\right)$, and the concentration inside the cuvette $\left(C_{\text {out }}\right)$. The SD of $C_{\mathrm{c}}$ was estimated for every $2 \mu \mathrm{mol} \mathrm{mol}{ }^{-1}$ change in the $\mathrm{CO}_{2}$ drawdown. The figure is based

$W U E_{\mathrm{t}}=\left\{\begin{array}{l}a) \text { from } \Delta^{13} C \rightarrow W U E_{\Delta}=\frac{\left(C_{\text {out }}-C_{\mathrm{i}}\right) * V P D}{1.6} \\ b) \text { from gas exchange } \rightarrow W U E_{\mathrm{G}}=\frac{A_{\text {net }}}{E}\end{array}\right\}$

where $C_{\mathrm{i}}$ is solved from a theoretical $\Delta^{13} \mathrm{C}$ model.

We considered three models for $\Delta^{13} \mathrm{C}$, which resulted in three estimations of $\mathrm{WUE}_{\Delta}$. First we estimated $C_{\mathrm{i}}$ from the simple model by Farquhar et al. (1982), as

$C_{\mathrm{i}}=C_{\text {out }} * \frac{\Delta_{\mathrm{o}}-a_{\mathrm{s}}}{\bar{b}-a_{\mathrm{s}}}$

where $\bar{b}$ is taken as $27 \%$, a standard value for $\mathrm{C}_{3}$ plants, that was derived empirically from relationships between $\delta^{13} \mathrm{C}$ of leaf bulk material and $C_{\mathrm{i}} / C_{\mathrm{a}}$ values (Farquhar et al. 1982; Cernusak et al.2013; Ubierna and Farquhar 2014). This model does not account specifically for the dependency of $\Delta^{13} \mathrm{C}$ on $g_{\mathrm{m}}, R_{\mathrm{d}}$ or photorespiration $\left(R_{\mathrm{p}}\right)$; instead it includes these effects empirically within $\bar{b}$, which is often sufficient in practice (Cernusak et al. 2013; Bloomfield et al. 2019). Second, we estimated $C_{\mathrm{i}}$ from a model proposed by Seibt et al. (2008), subsequently referred to as the partial model, as

$C_{\mathrm{i}}=C_{\text {out }} * \frac{\Delta_{\mathrm{o}}-a_{\mathrm{s}}+\left(b-a_{\mathrm{m}}\right) \frac{g_{\mathrm{s}}}{1.6 * g_{\mathrm{m}}}+f \frac{\Gamma^{*}}{C_{\mathrm{out}}}}{b-a_{\mathrm{s}}+\left(b-a_{\mathrm{m}}\right) \frac{g_{\mathrm{s}}}{1.6 * g_{\mathrm{m}}}}$

where $\Gamma^{*}$ is the $\mathrm{CO}_{2}$ compensation point, derived from an Arrhenius function (Bernacchi et al. 2001; Medlyn et al. 2002 Eq. 12). This model accounts explicitly for the effect of $g_{\mathrm{m}}$ and $R_{\mathrm{p}}$ and assumes negligible effect of $R_{\mathrm{d}}$. Finally, from the comprehensive model of Farquhar and Cernusak (2012) $C_{\mathrm{i}}$ can be solved as (see supplemental materials in Cernusak et al. 2018) on non-filtered data. $\mathbf{b}$ The diurnal time course of the $\mathrm{CO}_{2}$ drawdown. The whiskers of the box-plots extend to 1.5 times the interquartile range. The grey area marks the time of day excluded from the analysis. The figure is based on non-filtered data

$C_{\mathrm{i}}=\frac{-\mathrm{II} \pm \sqrt{\mathrm{II}^{2}-4 \mathrm{I} * \mathrm{III}}}{2 \mathrm{I}}$

where equations I, II and III are given in the supplementary materials (Eqn S9-S11). This model accounts explicitly for $g_{\mathrm{m}}, R_{\mathrm{p}}$ and $R_{\mathrm{d}}$, and it includes a correction for the ternary effect.

To avoid circularity, we divided our data set into two parts. We used 4 days' data to estimate a mean value of $g_{\mathrm{m}}$ $\left(0.29 \mathrm{~mol} \mathrm{CO}_{2} \mathrm{~m}^{-2} \mathrm{~s}^{-1} \mathrm{bar}^{-1}\right)$. Subsequently, this mean $g_{\mathrm{m}}$ was used on the remaining 5 days' data to estimate $C_{\mathrm{i}}$ from $\Delta^{13} \mathrm{C}$ (Eqs. 4, 5 and 6) and WUE (Eq. 3). Note that the 4-day mean $g_{\mathrm{m}}$ was slightly different from the mean for all 9 days together, which was $0.31 \mathrm{~mol} \mathrm{CO}_{2} \mathrm{~m}^{-2} \mathrm{~s}^{-1} \mathrm{bar}^{-1}$. For the comprehensive model, besides using a constant mean $g_{\mathrm{m}}$, we also performed the calculations using either a constant $g_{\mathrm{m}} / g_{\mathrm{s}}(2.9)$ or infinite $g_{\mathrm{m}}$ and compared these estimates as well to $\mathrm{WUE}_{\mathrm{G}}$.

\section{Data analysis}

A statistical filter was applied to the dataset to discard outliers in $C_{\mathrm{i}}-C_{\mathrm{c}}$ and $g_{\mathrm{m}}$. Any data point outside the range of mean $\pm 3 \mathrm{SD}$ was considered an outlier and removed. This filter removed $4.5 \%$ of the data. Despite the filtering, some few negative conductances remained. Although they are not theoretically possible, we retained them in the analysis because they represent the tails of the statistical distributions and they influenced the means. The sole exception was when we analysed the dependency of net photosynthetic rates on the conductances. In this one analysis, the negative values were deleted. The four cuvettes were treated as biological 
replicates, from which the mean hourly values were used for further analysis. Regression analysis was used to evaluate diurnal patterns. This included linear, polynomial, and nonlinear regression, as deemed appropriate. Correlations were treated as significant for $p \leq 0.05$. All variability is given as standard error, unless stated otherwise. All statistical analyses were performed using the base package of $\mathrm{R}$ (version 3.3.2).

\section{Results}

\section{Diurnal trends of $g_{s}$ and $g_{m}$}

We evaluated the diurnal trends in stomatal and mesophyll conductance, and in their ratio. Mean $g_{\mathrm{s}}$ was 0.115 $(\mathrm{SE}=0.002) \mathrm{mol} \mathrm{CO}_{2} \mathrm{~m}^{-2} \mathrm{~s}^{-1} \mathrm{bar}^{-1}$. As expected, $g_{\mathrm{s}}$ showed a significant diurnal pattern $(F=79.17, p<0.001)$, with peak values between 09:00 and 10:00, and decreased thereafter (Fig. 2a). We found a mean $g_{\mathrm{m}}$ value of $0.31(\mathrm{SE}=0.02) \mathrm{mol}$ $\mathrm{CO}_{2} \mathrm{~m}^{-2} \mathrm{~s}^{-1}$ bar $^{-1}$. Furthermore $g_{\mathrm{m}}$ also had a significant diurnal pattern $(F=13.52, p<0.001$; Fig. $2 b)$ with relatively stable mean values between 08:00 and 16:00 and lower values in the early morning and towards the evening. The mean for the unitless ratio $g_{\mathrm{m}} / g_{\mathrm{s}}$ was $2.67(\mathrm{SE}=0.3)$; with a weak, but significant diurnal pattern $(F=3.9, p=0.02)$.

\section{The relationship of $A_{\text {net }}$ to $g_{s}$ and $g_{m}$}

$A_{\text {net }}$ followed a typical diurnal pattern, with highest rates between 08:00 and 12:00, with a mean of $16.2(\mathrm{SE}=0.26)$ $\mu \mathrm{mol} \mathrm{CO}_{2} \mathrm{~m}^{-2} \mathrm{~s}^{-1}$, and gradually declining rates in the afternoon (Fig. 2c). We found a significant asymptotic relationship between $A_{\text {net }}$ and $g_{\mathrm{s}}\left(p<0.001, R^{2}=0.53\right.$, Fig. 3a). Similarly there was a significant asymptotic relationship between $A_{\text {net }}$ and $g_{\mathrm{m}}\left(p<0.001, R^{2}=0.28\right.$, Fig. $\left.3 \mathrm{~b}\right)$.

\section{Relationship of $g_{\mathrm{s}}$ and $g_{\mathrm{m}}$ to VPD}

The average hourly VPD varied from $0.26 \mathrm{kPa}$ to $1.82 \mathrm{kPa}$ during the day, with sharp increase during the mornings until about 12:00 (Fig S4). We found a significant linear relationship between $g_{\mathrm{s}}$ and $V P D\left(F=37.6, p<0.001, R^{2}=0.26\right)$ (Fig. 4a) but no relationship between $g_{\mathrm{m}}$ and $\operatorname{VPD}(F=1.12$, $\left.p=0.3, R^{2}=0.001\right)$ (Fig. 4b).

\section{Contrasting estimates of WUE from $\Delta^{13} \mathrm{C}$}

We compared the performance of the three models to estimate WUE from $\Delta^{13} \mathrm{C}\left(\mathrm{WUE}_{\Delta}\right)$ against direct measurements of WUE as $A_{\text {net }} / E$ by the gas exchange system $\left(W^{\prime} E_{G}\right)$. Theoretically $\mathrm{WUE}_{\Delta}$ and $\mathrm{WUE}_{\mathrm{G}}$ should be identical with an ideal fit, where slope $m=1$ and intercept $a=0$. Using

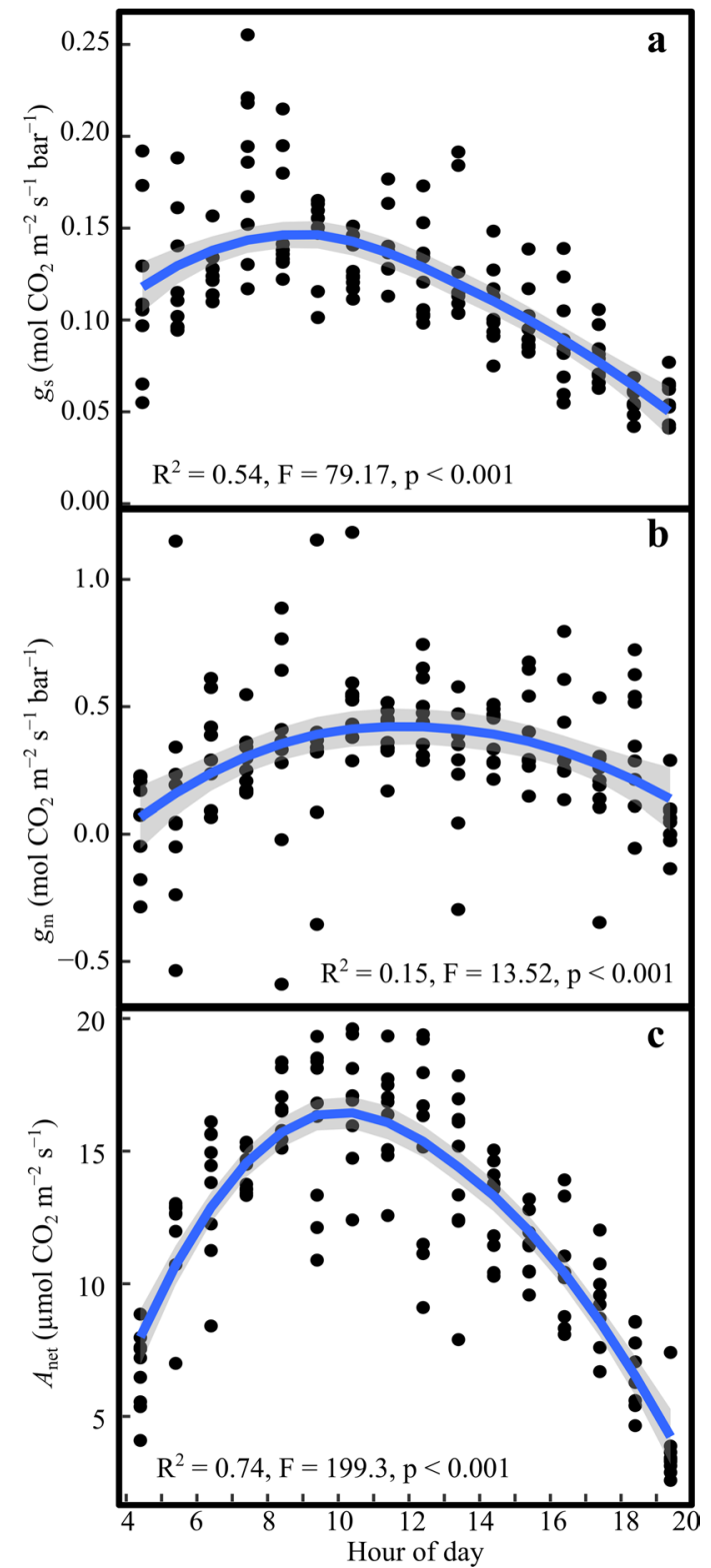

Fig. 2 Diurnal variation in a stomatal conductance $\left(g_{\mathrm{s}}\right)$, b mesophyll conductance $\left(g_{\mathrm{m}}\right)$, and $\mathbf{c}$ net photosynthesis $\left(A_{\text {net }}\right)$. The points represent the cuvette means $(n=4)$ for each hour and day. The blue line is the second order polynomial fit to the data and the shaded grey area is the standard error of the fit

the simple model resulted in a poor fit to our data (Fig. 5a). Further analysis revealed that this model could not predict $\mathrm{WUE}_{\mathrm{G}}$ in the early hours (04:00-08:00), but fit the data well between 08:00 and 20:00 $\left(a=-0.4, m=1.0, R^{2}=0.69\right.$, Fig S5). The partial model consistently overestimated $\mathrm{WUE}_{\mathrm{G}}$ by ca. $15 \%$ with no diurnal pattern (Fig. 5b). The comprehensive model matched the data well on average (Fig. 5c), but had a slight tendency to overestimate $\mathrm{WUE}_{\mathrm{G}}$ in the low range and underestimate it in the high range. Furthermore, it introduced more variability into the estimates compared 


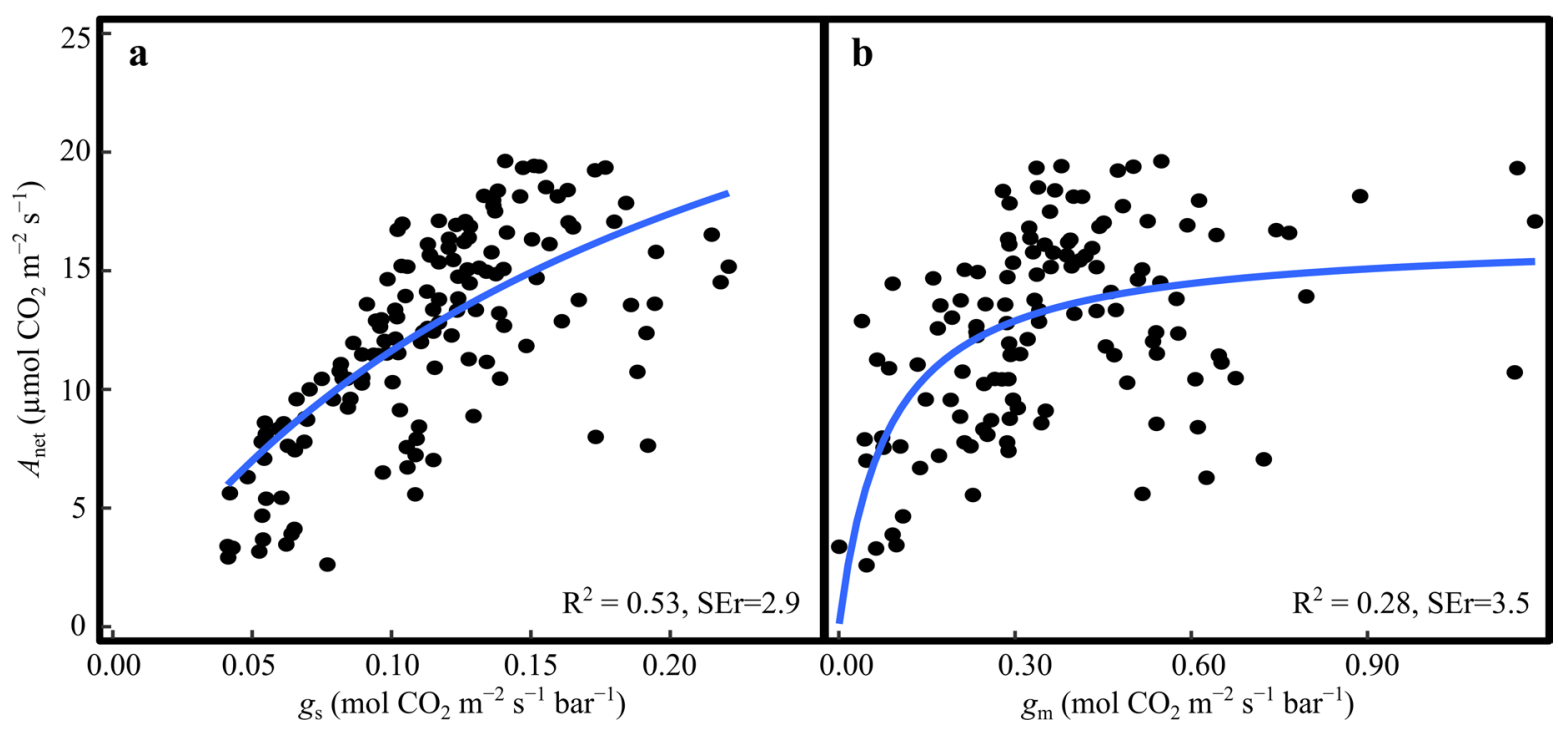

Fig. 3 Relationship between net photosynthesis $\left(A_{\text {net }}\right)$ and a stomatal conductance $\left(g_{\mathrm{s}}\right)$, and $\mathbf{b}$ mesophyll conductance $\left(g_{\mathrm{m}}\right)$. The points represent the cuvette means $(n=4)$ for each hour and day. The blue line represents the asymptotic fit to the data

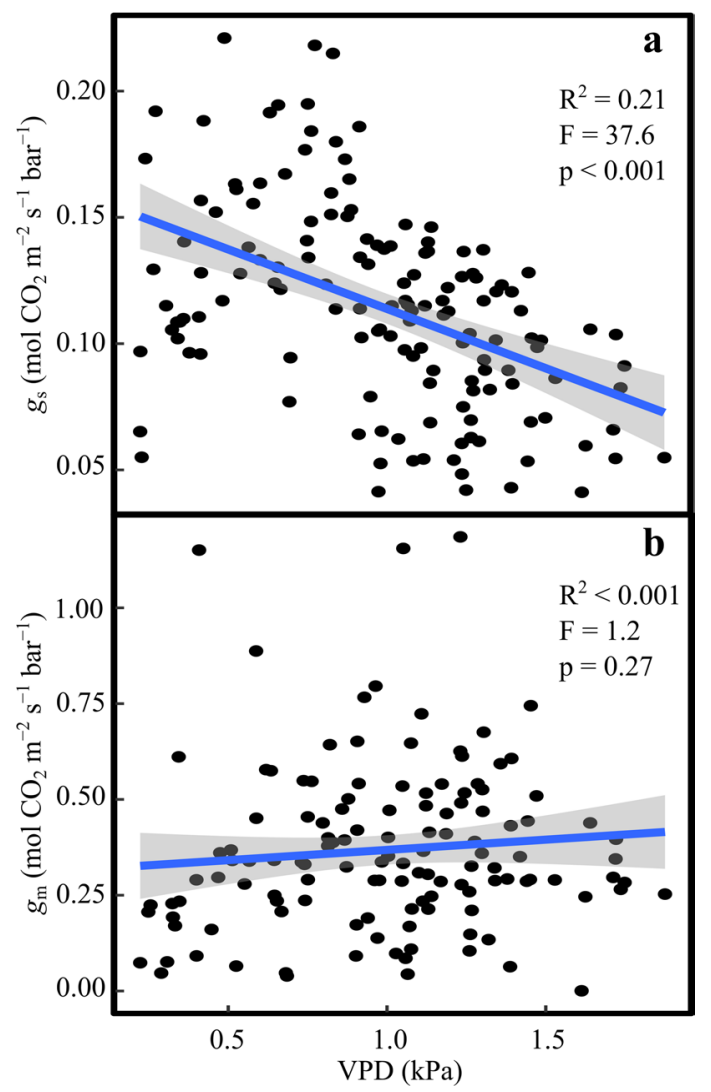

Fig. 4 Response of a stomatal $\left(g_{\mathrm{s}}\right)$, and b mesophyll $\left(g_{\mathrm{m}}\right)$ conductance to vapour pressure deficit $(V P D)$. The points represent the cuvette means $(n=4)$ for each hour and day. The blue line represents the regression fit to the data and the shaded grey area is the standard error of the fit to the partial model, with a residual standard error (SEr) of $2.7 \mathrm{mmol} \mathrm{CO}_{2}$ mol $\mathrm{H}_{2} \mathrm{O}^{-1}\left(R^{2}=0.61\right)$ compared to $2.1 \mathrm{mmol} \mathrm{CO}_{2} \mathrm{~mol} \mathrm{H}_{2} \mathrm{O}^{-1}\left(R^{2}=0.78\right)$. In the comprehensive model, representing $g_{\mathrm{m}}$ as a constant ratio to $g_{\mathrm{s}}$ overestimated $\mathrm{WUE}_{\mathrm{G}}$ by ca. $9 \%$ compared to observations $(a=0.7$, $m=1.05$, Fig. S6a). Assuming infinite $g_{\mathrm{m}}$ resulted in a poor fit to observed data ( $a=0.7, m=1.5$, Fig. S6b) and an overestimation of $\mathrm{WUE}_{\mathrm{G}}$ by $49 \%$.

\section{Discussion}

Here, we report the first $g_{\mathrm{m}}$ estimates for mature Pinus sylvestris, one of the most widespread coniferous species of the northern hemisphere. Our mean value $(0.31$, $\left.\mathrm{SE}=0.02 \mathrm{~mol} \mathrm{~m}^{-2} \mathrm{~s}^{-1} \mathrm{bar}^{-1}\right)$ is somewhat higher than previously reported for other Pinus species (Flexas et al. 2008), but it is within the range of values reported for various conifers (Table 1) (De Lucia et al. 2003; Flexas et al. 2008; Bown et al. 2009; Bickford et al. 2010; Han 2011; Maseyk et al. 2011; Ubierna and Marshall 2011; Veromann-Jürgenson et al. 2017). Some of this variation may be due to differences in the methods used (Flexas et al. 2008). In particular, the "variable $J$ method", which uses simultaneous measurements of gas exchange and chlorophyll fluorescence to infer $g_{\mathrm{m}}$, generally yields lower $g_{\mathrm{m}}$ values than do isotopic techniques. If we exclude the "variable $J$ " estimates from the list in Table 1, then our estimate of $g_{\mathrm{m}}$ matches the other values for conifers quite well. Furthermore, our estimates of $\delta^{13} \mathrm{C}$ of $A_{\text {net }}$ were in the range reported previously (e.g. Wingate et al. 2010) (Fig. S7), and are the first based on measurements using 


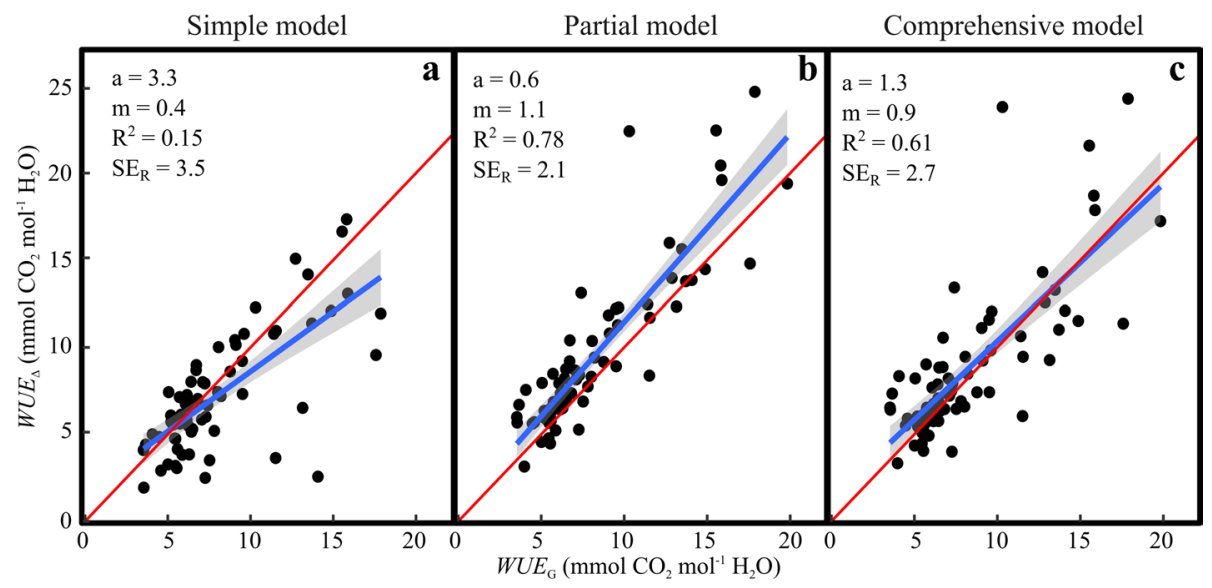

Fig. 5 Water-use efficiency calculated from $\Delta^{13} \mathrm{C}$ data $\left(\mathrm{WUE}_{\Delta}\right)$ using $\mathbf{a}$ the simple model $\mathbf{b}$ the partial model, and $\mathbf{c}$ comprehensive model presented here. The results are compared to water-use efficiency calculated from continuous gas exchange data $\left(\mathrm{WUE}_{\mathrm{G}}\right)$. In model $\mathbf{b}$ and c we assume a constant vale for $g_{\mathrm{m}}\left(0.29 \mathrm{~mol} \mathrm{CO}_{2} \mathrm{~m}^{-2} \mathrm{~s}^{-1} \mathrm{bar}^{-1}\right)$.
The points represent the cuvette means $(n=4)$ for each hour and day. The blue line is the linear fit to the data, the shaded grey area is the standard error of the fit, and $\mathrm{m}$ is the slope of the fit. The red line represents the theoretical 1:1 fit for comparison

Table 1 Mesophyll conductance values reported for various coniferous species

\begin{tabular}{llll}
\hline Measurement method & Species & $g_{\mathrm{m}} \mathrm{mol} \mathrm{m}^{-2} \mathrm{~s}^{-1} \mathrm{bar}^{-1 * *}$ & References \\
\hline Instantaneous $\Delta^{13} \mathrm{C}$ and gas exchange (CRDS) & Pinus sylvestris & $0.33 \pm 0.03$ & Current paper \\
Instantaneous $\Delta^{13} \mathrm{C}$ and gas exchange & Pinus halepensis & $0.2-0.4$ & Maseyk et al. (2011) \\
Instantaneous $\Delta^{13} \mathrm{C}$ and gas exchange (TDL) & Juniperus monosperma & $0.04-4.0$ & Bickford et al. (2009) \\
Instantaneous $\Delta^{13} \mathrm{C}$ and gas exchange & Pseudotsuga menziesii & $0.14-0.20$ & Warren et al. (2003) \\
Phloem $\delta^{13} \mathrm{C}$ & Pseudotsuga menziesii & $0.22 \pm 0.11$ & Ubierna and Marshall (2011) \\
Phloem $\delta^{13} \mathrm{C}$ & Thuja plicata & $0.09 \pm 0.04$ & Ubierna and Marshall (2011) \\
Phloem $\delta^{13} \mathrm{C}$ & Larix occidentalis & $0.41 \pm 0.21$ & Ubierna and Marshall (2011) \\
Variable J method & Pinus radiata & $0.153 \pm 0.002$ & De Lucia et al. (2003) \\
Variable J method & Pinus sylvestris & $0.124 \pm 0.009$ & Veromann-Jürgensson et al. (2017) \\
Variable J method & Pinus radiata & $0.16-0.2$ & Bown et al. (2009) \\
Variable J method & Pinus densiflora & $0.107-0.250$ & Han (2011) \\
Various methods & Pinus spp.* & $0.04-0.17$ & Flexas et al. (2008)
\end{tabular}

* Pinus lambertiana, Pinus monticola, Pinus pinaster, Pinus radiata

**If published values were presented as $\mathrm{mol} \mathrm{m}^{-2} \mathrm{~s}^{-1}$, then we assumed barometric pressure of 1 bar and converted the units to mol $\mathrm{m}^{-2} \mathrm{~s}^{-1} \mathrm{bar}^{-1}$

the CRDS (cavity ring-down spectroscopy) technology. The good agreement encourages us to suggest that this method, which is less expensive than most alternatives, produces reliable $\delta^{13} \mathrm{C}$ measurements and is suitable for field applications. The CRDS was steady under the variable conditions of field-measurements, exemplified by the fact that we did not see any drift in the $\delta^{13} \mathrm{C}$ values of the reference gases during several weeks of continuous measurements (Fig. S3). Nevertheless, it was crucial to correct the data for the CRDS' sensitivity to changing $\mathrm{CO}_{2}$ and $\mathrm{H}_{2} \mathrm{O}$ vapour concentrations. The sensitivity of isotope measurements to $\mathrm{CO}_{2}$ concentration is a known phenomenon and is commonly corrected for in other laser technologies, like in lead alloy tunable diode lasers (Ubierna et al. 2018). Furthermore, drying the gas before isotope analysis will avoid having to correct for $\mathrm{H}_{2} \mathrm{O}$ concentrations dependency, which is likely to improve measurement accuracy.

We observed an asynchronous reduction in $g_{\mathrm{m}}$ and $g_{\mathrm{s}}$ over the day (Fig. 2a, b). This may happen because $g_{\mathrm{s}}$ is under strong control by ambient $V P D$ (Fig. 4a), whereas we found no correlation between $g_{\mathrm{m}}$ and $V P D$ (Fig. 4b). The response of $g_{\mathrm{m}}$ to $V P D$ has only been investigated in few studies, and with contrasting results. While Bongi and Loreto (1989) and Loucos et al. (2017) found a significant negative correlation between $g_{\mathrm{m}}$ and $V P D$, a study looking at the effect of air humidity and soil moisture (Warren 2008c) on $g_{\mathrm{s}}$ and $g_{\mathrm{m}}$ found a strong correlation of both 
conductances to soil moisture, while $V P D$ only affected $g_{\mathrm{s}}$ and not $g_{\mathrm{m}}$. All studies involved different species, and higher $V P D$ ranges (1-3 $\mathrm{kPa}$ and $1-2 \mathrm{kPa}$, respectively) compared to our study $(0.23-1.82 \mathrm{kPa})$. These discrepancies highlight the need for further investigation including a wider range of $V P D$ conditions for Pinus sylvestris.

We fitted an asymptotic relationship of $A_{\text {net }}$ to $g_{\mathrm{s}}$ and $g_{\mathrm{m}}$. The asymptotic response agrees with theoretical expectations of $\mathrm{CO}_{2}$ saturation at high conductances. In a diurnal context, $A_{\text {net }}$ was maintained at high rates until midday, despite declining $g_{\mathrm{s}}$ from mid-morning (Fig. 2). We suggest that high $g_{\mathrm{m}}$ helped to maintain $A_{\text {net }}$ during the late morning, enabling high $C_{\mathrm{c}}$ and compensating for the decline of $g_{\mathrm{s}}$. This diurnal asynchrony between $g_{\mathrm{s}}$ and $g_{\mathrm{m}}$ is qualitatively similar to the observations by TherouxRancourt et al. (2014) on hybrid poplar cuttings exposed to soil drying over 12 days. They suggested based on daily measurements of $g_{\mathrm{s}}$ and $g_{\mathrm{m}}$ that a delayed $g_{\mathrm{m}}$ response reduced the decline in photosynthesis and enhanced WUE during the beginning of the drought treatment. Our finding suggests, that even within a diurnal context, the asynchronous response of $g_{\mathrm{m}}$ and $g_{\mathrm{s}}$ to environmental conditions has significant influence on $A_{\text {net }}$ and presumably WUE.

We compared three models to estimate WUE from $\delta^{13} \mathrm{C}$. We found that the simple model can estimate WUE well for most of the day. This model uses $\bar{b}$, an empirical value that accounts for the drop of concentration between $C_{\mathrm{i}}$ and $C_{\mathrm{c}}$, the different fractionations occurring during photosynthetic discrimination, as well as possible postphotosynthetic discrimination. Many studies have shown that $\bar{b}$ works well as an approximation (e.g. Farquhar et al. 1982; Seibt et al. 2008; Bloomfield et al. 2019). However, it performed poorly during the early morning, when WUE (Fig. S8), and especially $\delta^{13} \mathrm{C}$ of photosynthesis (Fig. S7) were more variable. This meant that it produced unreliable WUE estimates for $25 \%$ of the photosynthetically active period of the day. Our analysis clearly shows that a more complete model that accounts explicitly for the effects of photorespiration, or both photorespiration and daytime respiration, performs better under such variable conditions and provides more accurate estimates of WUE. The relatively high variability in the estimates highlight the need to further refine some of the model assumptions.

We have shown that it is critical to account for $g_{\mathrm{m}}$ in the estimation of WUE from $\Delta{ }^{13} \mathrm{C}$. This point has been made before (Seibt et al. 2008; Klein et al. 2015), but is still often neglected. Our data is yet an other example of WUE being overestimated if $g_{\mathrm{m}}$ is assumed to be infinite, and we show that assuming constant $g_{\mathrm{m}} / g_{\mathrm{s}}$ or constant $g_{\mathrm{m}}$ both yield better estimates than infinite $g_{\mathrm{m}}$. Estimating WUE from $g_{\mathrm{m}} / g_{\mathrm{s}}$ had the further advantage of accounting for some of the diurnal change in $g_{\mathrm{m}}$, resulting in a slope closer to 1 than when $g_{\mathrm{m}}$ was assumed constant.
Nevertheless, this approach does not take into account the diurnality of $g_{\mathrm{m}} / g_{\mathrm{s}}$ itself, and neglects the fact that $g_{\mathrm{m}}$ is much less strongly correlated with VPD than $g_{s}$.

The current study presents the first estimate of $g_{\mathrm{m}}$ for mature Pinus sylvestris trees, one of the most wide-ranging tree species in the world. Those estimates were derived with a CRDS/gas exchange system, which presents opportunities for simplifying the measurement of online $\Delta^{13} \mathrm{C}$ discrimination. The measurements were made continuously and in the field over several sunny days in the summer. The high temporal resolution of our data allowed us to evaluate diurnal trends in conductance in relation to $A_{\text {net }}$, and test different models to estimate WUE form $\Delta^{13} \mathrm{C}$. Our analysis revealed that the simple model to account for ${ }^{13} \mathrm{C}$ discrimination worked well, but only under stable conditions, and that the comprehensive model has the potential to account for variable conditions and provide reliable estimates of $C_{\mathrm{i}}$ and WUE. We highlight the need for further work under a broader range of environmental conditions, and including seasonal phenology. Our $g_{\mathrm{m}}$ estimate provides a means of improving inferences of WUE from $\Delta{ }^{13} \mathrm{C}$ and our continuous measurements provide a path forward to improve the modelling of $g_{\mathrm{m}}$ in the future.

Acknowledgements This work was supported by the Knut \& Alice Wallenberg Foundation (\#2015.0047), and the Swedish strategic research area BECC (Biodiversity and Ecosystem Services in a Changing Climate). The authors want to acknowledge the SLU Stable Isotope Laboratory (SSIL) (www.slu.se/en/departments/forest-ecology-manag ement/ssil) for the isotopic analysis of the calibration gases.

\section{Compliance with ethical standards}

Conflict of interest The authors have no conflict of interest to declare.

Open Access This article is distributed under the terms of the Creative Commons Attribution 4.0 International License (http://creativeco mmons.org/licenses/by/4.0/), which permits unrestricted use, distribution, and reproduction in any medium, provided you give appropriate credit to the original author(s) and the source, provide a link to the Creative Commons license, and indicate if changes were made.

\section{References}

Bernacchi C, Singsaas E, Pimentel C, Portis AR Jr, Long SP (2001) Improved temperature response functions for models of Rubisco limited photosynthesis. Plant, Cell Environ 24(2):253-259

Bernacchi CJ, Portis AR, Nakano H, von Caemmerer S, Long SP (2002) Temperature response of mesophyll conductance. Implications for the determination of Rubisco enzyme kinetics and for limitations to photosynthesis in vivo. Plant Physiol 130(4):1992-1998

Bickford C, McDowell N, Erhardt E, Hanson D (2009) High-frequency field measurements of diurnal carbon isotope discrimination and internal conductance in a semi-arid species, Juniperus monosperma. Plant, Cell Environ 32(7):796-810 
Bickford CP, Hanson DT, McDowell NG (2010) Influence of diurnal variation in mesophyll conductance on modelled 13C discrimination: results from a field study. J Exp Bot 61(12):3223-3233

Bloomfield KJ, Prentice IC, Cernusak LA, Eamus D, Medlyn BE, Rumman R, Wright IJ, Boer MM, Cale P, Cleverly J, Egerton JJ, Ellsworth DS, Evans BJ, Hayes LS, Hutchinson MF, Liddell MJ, Macfarlane C, Meyer WS, Togashi HF, Wardlaw T, Zhu L, Atkin OK (2019) The validity of optimal leaf traits modelled on environmental conditions. New Phytol 221:1409-1423. https:// doi.org/10.1111/nph.15495

Bongi G, Loreto F (1989) Gas-exchange properties of salt-stressed olive (Olea europea L.) leaves. Plant Physiol 90(4):1408-1416

Bown HE, Watt MS, Mason EG, Clinton PW, Whitehead D (2009) The influence of nitrogen and phosphorus supply and genotype on mesophyll conductance limitations to photosynthesis in Pinus radiata. Tree Physiol 29(9):1143-1151

Bunce JA (2010) Variable responses of mesophyll conductance to substomatal carbon dioxide concentration in common bean and soybean. Photosynthetica 48(4):507-512

Campany CE, Tjoelker MG, von Caemmerer S, Duursma RA (2016) Coupled response of stomatal and mesophyll conductance to light enhances photosynthesis of shade leaves under sunflecks. Plant, Cell Environ 39(12):2762-2773

Cernusak LA, Ubierna N, Winter K, Holtum JAM, Marshall JD, Farquhar GD (2013) Environmental and physiological determinants of carbon isotope discrimination in terrestrial plants. New Phytol 200:950-965

Cernusak LA, Ubierna N, Jenkins MW, Garrity SR, Rahn T, Powers HH, Hanson DT, Sevanto S, Wong SC, McDowell NG, Farquhar GD (2018) Unsaturation of vapour pressure inside leaves of two conifer species. Sci Rep 8(1):7667

De Lucia EH, Whitehead D, Clearwater MJ (2003) The relative limitation of photosynthesis by mesophyll conductance in co-occurring species in a temperate rainforest dominated by the conifer Dacrydium cupressinum. Funct Plant Biol 30(12):1197-1204

Dewar R, Mauranen A, Mäkelä A, Hölttä T, Medlyn B, Vesala T (2017) New insights into the covariation of stomatal, mesophyll and hydraulic conductances from optimization models incorporating nonstomatal limitations to photosynthesis. New Phytol 217:571-585

Douthe C, Dreyer E, Epron D, Warren CR (2011) Mesophyll conductance to $\mathrm{CO}_{2}$, assessed from online TDL-AS records of ${ }^{13} \mathrm{CO}_{2}$ discrimination, displays small but significant short-term responses to $\mathrm{CO}_{2}$ and irradiance in Eucalyptus seedlings. J Exp Bot 62(15):5335-5346

Evans JR, von Caemmerer S (2013) Temperature response of carbon isotope discrimination and mesophyll conductance in tobacco. Plant, Cell Environ 36(4):745-756

Evans J, Sharkey T, Berry J, Farquhar G (1986) Carbon isotope discrimination measured concurrently with gas exchange to investigate $\mathrm{CO}_{2}$ Diffusion in Leaves of higher plants. Funct Plant Biol 13(2):281-292

Farquhar GD, Cernusak LA (2012) Ternary effects on the gas exchange of isotopologues of carbon dioxide. Plant, Cell Environ 35(7):1221-1231

Farquhar GD, von Caemmerer S, Berry JA (1980) A biochemical model of photosynthetic $\mathrm{CO}_{2}$ assimilation in leaves of $\mathrm{C} 3$ species. Planta 149(1):78-90

Farquhar GD, Ball MC, von Caemmerer S, Roksandic Z (1982) Effect of salinity and humidity on $\delta^{13} \mathrm{C}$ value of halophytes-evidence for diffusional isotope fractionation determined by the ratio of intercellular/atmospheric partial pressure of $\mathrm{CO}_{2}$ under different environmental conditions. Oecologia 52:121-124

Flexas J, Diaz-Espejo A, Galmés J, Kaldenhoff R, Medrano H, RibasCarbo M (2007) Rapid variations of mesophyll conductance in response to changes in $\mathrm{CO}_{2}$ concentration around leaves. Plant, Cell Environ 30(10):1284-1298

Flexas J, Ribas-Carbo M, Diaz-Espejo A, Galmés J, Medrano H (2008) Mesophyll conductance to $\mathrm{CO}_{2}$ : current knowledge and future prospects. Plant, Cell Environ 31(5):602-621

Flexas J, Galmés J, Gallé A, Gulias J, Pou A, Ribas-Carbo M, Tomas M, Medrano H (2010) Improving water use efficiency in grapevines: potential physiological targets for biotechnological improvement. Aust J Grape Wine Res 16(s1):106-121

Flexas J, Barbour MM, Brendel O, Cabrera HM, Carriquí M, DíazEspejo A, Douthe C, Dreyer E, Ferrio JP, Gago J, Gallé A, Galmés J, Kodama N, Medrano H, Niinemets Ü, Peguero-Pina JJ, Pou A, Ribas-Carbó M, Tomás M, Tosens T, Warren CR (2012) Mesophyll diffusion conductance to $\mathrm{CO}_{2}$ : an unappreciated central player in photosynthesis. Plant Sci 193:70-84

Galmés J, Conesa MA, Ochogavia JM, Perdomo JA, Francis DM, Ribas-Carbo M, Savé R, Flexas J, Medrano H, Cifre J (2011) Physiological and morphological adaptations in relation to water use efficiency in Mediterranean accessions of Solanum lycopersicum. Plant, Cell Environ 34(2):245-260

Guerrieri R, Lepine L, Asbjornsen H, Xiao J, Ollinger SV (2016) Evapotranspiration and water use efficiency in relation to climate and canopy nitrogen in U.S. forests. J Geophys Res 121(10):2610-2629

Han Q (2011) Height-related decreases in mesophyll conductance, leaf photosynthesis and compensating adjustments associated with leaf nitrogen concentrations in Pinus densiflora. Tree Physiol 31(9):976-984

Hasselquist NJ, Metcalfe DB, Högberg P (2012) Contrasting effects of low and high nitrogen additions on soil $\mathrm{CO}_{2}$ flux components and ectomycorrhizal fungal sporocarp production in a boreal forest. Glob Change Biol 18(12):3596-3605

Hassiotou F, Ludwig M, Renton M, Veneklaas EJ, Evans JR (2009) Influence of leaf dry mass per area, $\mathrm{CO}_{2}$, and irradiance on mesophyll conductance in sclerophylls. J Exp Bot 60(8):2303-2314

Hu J, Moore DJP, Riveros-Iregui DA, Burns SP, Monson RK (2010) Modeling whole-tree carbon assimilation rate using observed transpiration rates and needle sugar carbon isotope ratios. New Phytol 185(4):1000-1015

Keenan TF, Hollinger DY, Bohrer G, Dragoni D, Munger JW, Schmid HP, Richardson AD (2013) Increase in forest water-use efficiency as atmospheric carbon dioxide concentrations rise. Nature 499:324

Klein T, Rotenberg E, Tatarinov F, Yakir D (2015) Association between sap flow-derived and eddy covariance-derived measurements of forest canopy $\mathrm{CO}_{2}$ uptake. New Phytol 209(1):436-446

Lim H, Oren R, Palmroth S, Tor-ngern P, Mörling T, Näsholm T, Lundmark T, Helmisaari HS, Leppälammi-Kujansuu J, Linder S (2015) Inter-annual variability of precipitation constrains the production response of boreal Pinus sylvestris to nitrogen fertilization. For Ecol Manag 348:31-45

Loreto F, Tsonev T, Centritto M (2009) The impact of blue light on leaf mesophyll conductance. J Exp Bot 60(8):2283-2290

Loucos K, Simonin K, Barbour M (2017) Leaf hydraulic conductance and mesophyll conductance are not closely related within a single species. Plant, Cell Environ 40(2):203-215

Marshall JD, Monserud RA (1996) Homeostatic gas-exchange parameters inferred from ${ }^{13} \mathrm{C} /{ }^{12} \mathrm{C}$ in tree rings of conifers. Oecologia 105(1):13-21

Marshall JD, Waring RH (1984) Conifers and broadleaf species: stomatal sensitivity differs in western Oregon. Can J For Res 14:905-908

Maseyk K, Hemming D, Angert A, Leavitt SW, Yakir D (2011) Increase in water-use efficiency and underlying processes in pine forests across a precipitation gradient in the dry Mediterranean region over the past 30 years. Oecologia 167(2):573-585 
Medlyn B, Dreyer E, Ellsworth D, Forstreuter M, Harley P, Kirschbaum M, Roux X, Montpied P, Strassemeyer J, Walcroft A, Wang K, Loustau D (2002) Temperature response of parameters of a biochemically based model of photosynthesis. II. A review of experimental data. Plant, Cell Environ 25(9):1167-1179

Medlyn B, Duursma R, Eamus D, Ellsworth D, Prentice I, Barton C, Crous K, Angelis P, Fremman M, Wingate L (2011) Reconciling the optimal and empirical approaches to modelling stomatal conductance. Glob Change Biol 17(6):2134-2144

Oren R, Sperry JS, Katul GG, Pataki DE, Ewers BE, Phillips N, Schäfer KV (1999) Survey and synthesis of intra-and interspecific variation in stomatal sensitivity to vapour pressure deficit. Plant, Cell Environ 22:1515-1526

Pons TL, Flexas J, von Caemmerer S, Evans JR, Genty B, Ribas-Carbo M, Brugnoli E (2009) Estimating mesophyll conductance to $\mathrm{CO}_{2}$ : methodology, potential errors, and recommendations. J Exp Bot 60(8):2217-2234

Prentice IC, Dong N, Gleason SM, Maire V, Wright IJ (2014) Balancing the costs of carbon gain and water transport: testing a new theoretical framework for plant functional ecology. Ecol Lett 17(1):82-91

Rogers A, Medlyn BE, Dukes JS, Bonan G, von Caemmerer S, Dietze MC, Kattge J, Leakey ADB, Mercado LM, Niinemets Ü, Prentice CI, Serbin SP, Sitch S, Way DA, Zaehle S (2017) A roadmap for improving the representation of photosynthesis in Earth system models. New Phytol 213(1):22-42

Seibt U, Rajabi A, Griffiths H, Berry JA (2008) Carbon isotopes and water use efficiency: sense and sensitivity. Oecologia 155(3):441-454

Tarvainen L, Lutz M, Räntfors M, Näsholm T, Wallin G (2016) Increased needle nitrogen contents did not improve shoot photosynthetic performance of mature nitrogen-poor Scots pine trees. Front Plant Sci 7:1051

Tarvainen L, Wallin G, Lim H, Linder S, Oren R, Ottosson Löfvenius M, Räntfors M, Tor-ngern P, Marshall JD (2018) Photosynthetic re-fixation varies along stems and reduces $\mathrm{CO}_{2}$ efflux in mature boreal Pinus sylvestris trees. Tree Physiol 38(4):558-569

Tazoe Y, von Caemmerer S, Estavillo GM, Evans JR (2011) Using tunable diode laser spectroscopy to measure carbon isotope discrimination and mesophyll conductance to $\mathrm{CO}_{2}$ diffusion dynamically at different $\mathrm{CO}_{2}$ concentrations. Plant, Cell Environ 34(4):580-591

Théroux-Rancourt G, Éthier G, Pepin S (2014) Threshold response of mesophyll $\mathrm{CO}_{2}$ conductance to leaf hydraulics in highly transpiring hybrid poplar clones exposed to soil drying. J Exp Bot 65(2):741-753

Tholen D, Boom C, Noguchi K, Ueda S, Katase T, Terashima I (2008) The chloroplast avoidance response decreases internal conductance to $\mathrm{CO}_{2}$ diffusion in Arabidopsis thaliana leaves. Plant, Cell Environ 31(11):1688-1700

Ubierna N, Farquhar GD (2014) Advances in measurements and models of photosynthetic carbon isotope discrimination in $\mathrm{C} 3$ plants. Plant, Cell Environ 37:1494-1498

Ubierna N, Marshall JD (2011) Estimation of canopy average mesophyll conductance using $\delta^{13} \mathrm{C}$ of phloem contents. Plant, Cell Environ 34(9):1521-1535

Ubierna N, Holloway-Phillips MM, Farquhar GD (2018) Using stable carbon isotopes to study $\mathrm{C} 3$ and $\mathrm{C} 4$ photosynthesis: MODELS and calculations. In: Covshoff S (ed) Photosynthesis. Methods in molecular biology, vol 1770. Humana Press, New York
Uddling J, Wallin G (2012) Interacting effects of elevated $\mathrm{CO}_{2}$ and weather variability on photosynthesis of mature boreal Norway spruce agree with biochemical model predictions. Tree Physiol 32(12):1509-1521

Veromann-Jürgenson LL, Tosens T, Laanisto L, Niinemets Ü (2017) Extremely thick cell walls and low mesophyll conductance: welcome to the world of ancient living! J Exp Bot 68(7):1639-1653

Voelker S, Brooks R, Meinzer F, Anderson R, Bader M, Battipaglia G, Becklin K, Beerling D, Bert D, Betancourt J, Dawson TE, Domec J-C, Guyette R, Koerner C, Leavitt SW, Linder S, Marshall JD, Mildner M, Ogée J, Panyushkina I, Plumpton H, Pregitzer K, Saurer M, Smith A, Siegwolf R, Stambaugh M, Talhelm A, Tardif J, Van de Water P, Ward J, Wingate L (2016) A dynamic leaf gas-exchange strategy is conserved in woody plants under changing ambient $\mathrm{CO}_{2}$ : evidence from carbon isotope discrimination in paleo and $\mathrm{CO}_{2}$ enrichment studies. Glob Change Biol 22:889-902

Von Caemmerer S (2000) Biochemical models of leaf photosynthesis. Techniques in plant science, vol 2. CSIRO Publishing, Collingwood

Vrábl D, Vašková M, Hronková M, Flexas J, Šantrůček J (2009) Mesophyll conductance to $\mathrm{CO}_{2}$ transport estimated by two independent methods: effect of variable $\mathrm{CO}_{2}$ concentration and abscisic acid. $\mathrm{J}$ Exp Bot 60(8):2315-2323

Wallin G, Linder S, Lindroth A, Räntfors M, Flemberg S, Grelle A (2001) Carbon dioxide exchange in Norway spruce at the shoot, tree and ecosystem scale. Tree Physiol 21(12-13):969-976

Wang H, Zhao P, Zou LL, McCarthy HR, Zeng XP, Ni GY, Rao XQ (2014) $\mathrm{CO}_{2}$ uptake of a mature Acacia mangium plantation estimated from sap flow measurements and stable carbon isotope discrimination. Biogeosciences 11(5):1393-1411

Warren CR (2008a) Stand aside stomata, another actor deserves centre stage: the forgotten role of the internal conductance to $\mathrm{CO}_{2}$ transfer. J Exp Bot 59(7):1475-1487

Warren CR (2008b) Does growth temperature affect the temperature responses of photosynthesis and internal conductance to $\mathrm{CO}_{2}$ ? A test with Eucalyptus regnans. Tree Physiol 28(1):11-19

Warren CR (2008c) Soil water deficits decrease the internal conductance to $\mathrm{CO}_{2}$ transfer but atmospheric water deficits do not. J Exp Bot 59(2):327-334

Warren CR, Ethier GJ, Livingston NJ, Grant NJ, Turpin DH, Harrison DL, Black TA (2003) Transfer conductance in second growth Douglas-fir (Pseudotsuga menziesii (Mirb.)Franco) canopies. Plant, Cell Environ 26:1215-1227

Wei L, Marshall JD, Link TE, Kavanagh KL, Du E, Pangle RE, Gag PJ, Ubierna N (2014) A new $\delta^{13} \mathrm{C}$ submodel for 3-PG. Plant, Cell Environ 37:82-100

Wingate L, Seibt U, Moncrieff J, Jarvis P, Lloyd J (2007) Variations in ${ }^{13} \mathrm{C}$ discrimination during $\mathrm{CO}_{2}$ exchange by Picea sitchensis branches in the field. Plant, Cell Environ 30(5):600-616

Wingate L, Ogée J, Burlett R, Bosc A, Devaux M, Grace J, Loustau D, Gessler A (2010) Photosynthetic carbon isotope discrimination and its relationship to the carbon isotope signals of stem, soil and ecosystem respiration. New Phytol 188(2):576-589

Yamori W, Noguchi K, Hanba YT, Terashima I (2006) Effects of internal conductance on the temperature dependence of the photosynthetic rate in spinach leaves from contrasting growth temperatures. Plant Cell Physiol 47(8):1069-1080

Publisher's Note Springer Nature remains neutral with regard to jurisdictional claims in published maps and institutional affiliations. 